\title{
MAJÚ NAŠE VYSOKÉ ŠKOLY POMÁHAŤ RIEŠIŤ ZDRAVOTNÉ A SOCIÁLNE PROBLÉMY DOMA ALEBO V ROZVOJOVÝCH KRAJINÁCH?
}

\author{
Libuša Radková1, Miloš Velemínský ${ }^{2}$
}

12: 487,2010

ISSN $1212-4117$

${ }^{1}$ Trnavská univerzita v Trnavě, Fakulta zdravotníctva a sociálnej práce

2Jihočeská univerzita v Českých Budějovicích, Zdravotně sociální fakulta, katedra klinických oborů

Niektoré naše vysoké školy sa rozhodli pomáhat' riešit' zdravotné a sociálne problémy v rozvojových krajinách. Spomeňme len ich pracoviská v Keni, Sudáne, Burundi, Ugande, Zambii, Kambodži, Haiti, na Ukrajine, v Rusku, Rumunsku a inde. Často sa objavujú kritické hlasy voči takejto angažovanosti a pritom sa stavajú otázky, ktoré možno sumarizovat' asi takto: „Nemáme dost' problémov doma, ktoré treba riešit'? A prečo sa angažovat' ešte v rozvojovej pomoci??" Je zaujímavé, že tieto otázky stavajú hlavne tí, čo sa o žiadnu pomoc ani doma, ani v rozvojových krajinách nezaujímajú, a ešte menej sú ochotní sa do pomoci aktívne zapojit'.

Poslanie vysokých škôl so zdravotne sociálnymi fakultami je v mnohom podobné ostatným vysokým školám, vzdelávat' a vychovávat' svojich študentov $\mathrm{k}$ budúcemu povolaniu, učit' ich rešpektovat' l'udské práva, potláčat' akékol'vek prejavy rasizmu a xenofóbie, formovat' u nich pozitívny vzt'ah, ba lásku k povolaniu a konečne motivovat' ich k vedecko-výskumnej práci. Zdravotne sociálne fakulty naviac kladú pri svojich študentoch okrem teoretických vedomostí vel'ký dôraz na praktickú výchovu a vzdelanie. Praktická výchova sa uskutočňuje $\mathrm{v}$ zdravotníckych a sociálnych zariadeniach v najbližšom okolí fakúlt, počas letnej prázdninovej praxe $\mathrm{v}$ týchto zariadeniach ako aj $\mathrm{v}$ zariadeniach detašovaných pracovísk, kde sa učia študenti vnímat' zdravotné a sociálne problémy najmä rizikových skupín obyvatel'stva, tieto odhal'ovat', analyzovat', hladat' a nachádzat' riešenie. Dnes môžeme $\mathrm{k}$ výchovnému pôsobeniu pripočítat' aj motivovanie študentov $\mathrm{k}$ dobrovol'níckym aktivitám v rôznych spoločensky prospešných neziskových zariadeniach vich vol'nom čase, ved' urobit' niečo naviac, niečo, čo nie je mojou povinnost'ou, ale čím môžem prispiet' tým, ktorí to najviac potrebujú, patrí k naobohajúcejším zážitkom človeka. Prínos dobrovol'níkov oceňuje aj Európska únia, ktorá vyhlásila budúci rok za Európsky rok dobrovol'níkov, a do dobrovol'níc- kej činnosti sa zapájajú aj študenti a učitelia našich fakúlt.

Učia sa takto $v$ praxi vidiet' a poznat' problémy iných l'udí a zároveň zbavovat' sa egoizmu a tak častej vlastnosti u niektorých, ako je l'ahostajnost', nachádzanie vinníkov a kritizovanie pomerov. Naša spoločnost' však potrebuje nie kritikov, ale budúcich absolventov vysokých škôl, angažovaných sa aktívne zapájat' do riešenia spoločných problémov. Spomeňme len nezamestnanost', chudobu, civilizačné choroby, chronické choroby spojené so starnutím populácie, poruchy duševného zdravia, úrazy a ich následky a pod.

Ak bude moderný absolvent našich vysokých škôl odchádzat' do života obohatený vedomost'ami, ale zároveň len individualisticky a egoisticky orientovaný na seba, svoju rodinu, svoje záujmy a subjektívne potreby, je to príliš málo. Potom vidíme ako naliehavú požiadavku a potrebu celej spoločnosti urobit' pri výchove absolventov ovel'a viac. Veda a vedomosti, ktoré neslúžia humanite, nenapĺňajú svoje základné poslanie.

Naše malé krajiny sa tak prejavujú vo svete ako krajiny solidárne a spolu sa podielajúce na pomoci tým, ktorí to najviac potrebujú. Pred zemetrasením na Haiti, jednej z najchudobnejších krajín sveta, tam pôsobili naši lekári a zdravotníci a po zemetrasení boli medzi prvými, ktorí pomáhali a organizovali záchranné práce.

Učitel učí, vzdeláva a vychováva svojich študentov, ponúka im svoje vedomosti a skúsenosti, motivuje $\mathrm{k}$ štúdiu, ale najefektívnejšie pôsobenie je vosobnom príklade. Preto vítame zriadenie odboru rozvojové štúdie na Zdravotne sociálnej fakulte v Českých Budejoviciach. Nikdy sme neobchádzali zdravotné a sociálne problémy doma, ale prácou na rozvojových programoch sme získali nové skúsenosti a nadhl'ad tak užitočný pri riešení problémov aj doma.

\section{Libuša Radková, Miloš Velemínský} libusa.radkova@gmail.com 